\title{
ENTRE BOBBIO, MARX E MARXISTAS: POR UMA RETOMADA DE DIÁLOGOS
}

\section{BETWEEN BOBBIO, MARX AND MARXISTS: FOR A RESUMPTION OF DIALOGUES}

César Mortari Barreira'

RESUMO: A atual intensificaçăo da precarizaçấo da democracia liberal decorrente da articulaçăo entre o "novo liberalismo" (neoliberalismo) e o avanço global da financeirizaçăo da economia têm levantado sérias dúvidas quanto à capacidade de resistência daquele tipo de liberalismo mais atento às condiçóes sociais para o exercício da liberdade. Diante disso, o presente artigo defende que a compreensâo da relaçăo entre igualdade e liberdade, o tipo de aproximaçăo temática que caracterizam os escritos de Norberto Bobbio e, em particular, seus ricos diálogos com o marxismo, ainda possuem uma capacidade analítica superior a outras abordagens que enveredaram pelo chamado "giro antiprodutivista". Partindo da própria forma com que Bobbio avaliava o desenvolvimento dos estudos marxistas na década de 1970 e 1980, conclui-se que alguns de seus textos (até pouco tempo inéditos) podem servir como uma espécie de ponte para uma nova aproximaçăo entre liberais e marxistas.

PALAVRAS-CHAVE: Bobbio; marxismo; diálogo.

ABSTRACT: The current intensification of the precariousness of liberal democracy resulting from the articulation between the "new liberalism" (neoliberalism) and the global advance of the financialization of the economy has raised serious doubts about the resilience of that type of liberalism more attentive to the social conditions for the exercise of freedom. Thus, the present article argues that the understanding of the relation between equality and freedom, the type of thematic approach that characterizes the writings of Norberto Bobbio and, in particular, his rich dialogues with marxism, still have an analytical capacity superior to other approaches who went through the so-called "antiproductivist turn". Starting from Bobbio's own way of evaluating the development of marxist studies in the 1970s and 1980s, it follows that some of his previously unpublished texts may serve as a kind of bridge for a new and necessary reapprochement between liberals and marxists.

KEY WORDS: Bobbio; marxism; dialogue.

Doutorando em Teoria e Filosofia do Direito pela UERJ; Coordenador Científico do Instituto Norberto Bobbio. 


\section{INTRODUÇÃO}

Levar em conta as críticas feitas por Bobbio ao "novo liberalismo" (neoliberalismo) em defesa da democracia (BOBBIO, 2000, p. 85), bem como sua dúvida acerca da sobrevivência desta diante do poder dos mercados financeiros, de um lado, e daquele tipo de política do espetáculo característico da berlusconizaçăo da democracia (BOBBIO, 2016) do outro, é uma atitude fundamental para tentar compreender as espinhosas contradiçôes que vêm caracterizando o mundo nas últimas décadas. A percepçáo crítica da defesa intransigente da liberdade econômica por parte dos neoliberais, "da qual a liberdade política é apenas um corolário" (BOBBIO, 2000, p. 87), e a avaliaçăo de que a doutrina do "Estado mínimo" teria que acertar as contas com a tradiçăo do pensamento democrático, náo tanto no que se refere à democracia igualitária, mas à própria democracia formal (BOBBIO, 2000, p. 91), năo só oferecem uma sagaz chave de leitura para compreender nosso "processo" de impeachment, como demonstram a especial capacidade de Bobbio em levar a sério os conflitos que caracterizam a reproduçăo social da sociedade capitalista.

Felizmente, este tipo de raciocínio está muito distante do mainstream teórico atual, amplamente dominado por perspectivas normativas, e mais próximo dos processos particularmente perturbadores que vêm caracterizando o mundo nas últimas décadas. Neste sentido, seria de bom tom năo se deixar encantar por certos discursos sobre "globalizaçâo" e "sociedade de riscos", e atentar para uma simultaneidade bastante perturbadora, qual seja a expansăo global de ao menos quatro ondas após a década de 1970: (i) das chamadas "democracias constitucionais" (após o fim do "socialismo real", o mencionado "fim da história" caracterizou-se pela expansăo deste tipo de regime político liberal); (ii) da semântica dos direitos humanos como meio de emancipaçáo social; (iii) da desigualdade social e do endividamento pessoal (com a expressiva concentraçăo de renda e riqueza paralelas); e (iv) dos dispositivos de controle associados aos mecanismos de puniçáo (com a expansăo do direito penal, por exemplo).

Em outras palavras: desde que o regime neoliberal politicamente se enraizou pelo mundo, e certa construçăo teórica consagrou a esfera comunicativa frente à suposta "pacificaçâo do conflito de classe" que caracterizaria a formaçăo capitalista do Estado de Bem-Estar Social (HABERMAS, 1987, p. 491), nunca existiram tantos países democráticos, nunca tivemos tanto consenso quanto à força e importância dos direitos humanos e do Estado constitucional e, hoje, nunca tivemos uma concentraçăo do capital e uma desigualdade mundial da riqueza tăo alarmantes (PIKETTY, 2014, p. 419), acompanhadas de sistemáticas violaçôes de direitos trabalhistas, instrumentalizaçăo do direito internacional para a propagaçăo de intervençōes "humanitárias" (RICOBOM, 2010, p. 171) que reforçam desigualdades globais (GONÇALVES; COSTA, 2016), alargamento expressivo dos dispositivos de controle do sistema de justiça criminal e uma crescente "militarizaçăo da vida urbana" (GRAHAM, 2016, p. 121).

Em nosso plano nacional, a articulaçáo dessas expansôes se dá de forma ainda mais "instigante". É justamente durante o processo de democratizaçăo do país que observamos o "boom" do encarceramento e a contínua e cada vez mais intensificada super-exploraçáo do trabalhador. Mas se no início do século XXI vivenciávamos um suposto "pacto popular democrático" desenvolvimentista, sem qualquer conflito de 
classes, como habermasiadamente propugnava Bresser-Pereira (BRESSER-PEREIRA, 2012, p. 121), como compreender a concomitante intensificaçăo das desigualdades sociais (rasteiramente problematizadas por modelos focalizados de assistência social, como o "Bolsa Família") e da exploraçăo do trabalho?

Diante dessas situaçōes, a principal estratégia tradicional de setores progressistas tem sido apelar para a defesa de uma normatividade democrática, cujos inúmeros eventos "em defesa da legalidade" e as publicaçōes, seminários e encontros que questionam "a falta de respeito à Constituiçấo" constituem exemplos sintomáticos. O que há em comum nessas estratégias de percepçâo, enfrentamento e resoluçăo dos problemas?

Resumidamente, pode-se dizer que a premissa norteadora desses discursos é a crença de que a alteraçâo material do mundo é fruto de uma inflexáo teórica. Cria-se, assim, a costumeira imagem de que "uma prática específica é consequência de uma teoria específica" (RUSCHE; KIRCHHEIMER, 2004, p. 197). Como se ideias fossem capazes de estabelecer um direcionamento claro, inequívoco e nâo contraditório para o agir. Como se a realidade material fosse errada, e o certo estivesse na enunciaçáo, na norma, exterior e, por isso mesmo, imune à realidade, que passa a ser considerada como algo "desajustado" à normatividade.

Esse idealismo aproxima-se, sugestivamente, da filosofia do como se, tal como consagrado por Hans Vaihinger, no sentido de que as ideias sâo em si mesmas ficçôes. Ainda que sejam "falsas" no âmbito teórico, sâo justificadas por serem "praticamente verdadeiras", isto é, por estabelecerem as condiçōes apropriadas para um agir específico (VAIHINGER, 2011, p. 99). Como, entăo, questionar o tipo de especificidade que articula isso tudo? $O$ importante aqui seria problematizar o chamado "suporte material" das imaterialidades - teorias, códigos de comunicaçâo, tecnologias (PFEIFFER, 1994, p. 02) - e, com isso, “compreender a inovaçăo teórica como uma expressáo de uma necessidade ou de uma mudança já acontecida na práxis social" (RUSCHE; KIRCHHEIMER, 2004, p. 197).

No entanto, o desacordo entre "realidade" e "norma" ainda é majoritariamente abordado a partir de um projeto normativo, em especial em autores que aderiram ao chamado "giro antiprodutivista" na teoria social (GONÇALVES, 2016, p. 61). Diante disso, Bobbio está saudavelmente descolado. Seu método de aproximaçăo sucessiva às mais variadas temáticas o permitiam nutrir uma especial desconfiança diante de "teorias gerais" e entusiasmos especulativos. Adepto confesso do "realismo político" que partia do conflito e da dominaçaáo, e também um crítico do tipo de conservadorismo que informava essas análises (Hobbes), seu pensamento nunca deixou de atentar para as especiais dificuldades que movimentavam os esforços democráticos.

\section{0 GIRO ANTIPRODUTIVISTA NA TEORIA SOCIAL}

Mas antes de fazer uma breve aproximaçăo às ricas reflexóes de Bobbio, é importante caracterizar com mais rigor o tipo de análise frente à qual o "working in progress" bobbiano (LAFER, 2013, p. 23) se contrapóe. Se as discussóes na década de 1950 e 1960 giravam em torno de conceitos como os de "conflito social", "classe", "sociabilizaçáo" e "exploraçâo", como foi possível que nos últimos 40 anos a teoria 
social passasse a enfatizar a "governança global" organizada por "setores", executada por uma "sociedade civil voluntarista" e baseada em "organizaçôes internacionais" e "comunidades epistêmicas" (STREECK, 2016, p. 23)?

Este é o significado da já mencionada expressăo "giro antiprodutivista" do pensamento social: desde os anos 1970, uma série de diagnósticos passaram a sustentar a "perda de centralidade da categoria trabalho" (Offe) em substituiçâo pela "esfera comunicacional" (Habermas) (ANTUNES, 2015, p. 207), realizando "um progressivo abandono do conflito socioeconômico como objeto de investigaçăo" (GONÇALVES, 2017, p. 1033). Neste contexto, a teoria social năo só esqueceu que "na história real (...) o papel principal é desempenhado pela conquista, a subjugação, o assassínio para roubar, em suma, a violência. Já na economia política, tăo branda, imperou sempre o idílio" (MARX, 2013, p. 786), como passou a acreditar que os mecanismos discursivos e intersubjetivos seriam suficientes para combater a desigualdade social. Neste contexto, como uma teoria social que ignorou a crítica da economia política responde às sucessivas crises (financeira, alimentícia, ambiental, migratória)?

Resposta: ela reforça - sem perceber e problematizar a produçăo da ordem jurídico-política enquanto estrutura fundamental à reproduçấo social capitalista - o posicionamento da norma como medida exterior à realidade. Consequentemente, as desigualdades, os "crimes", as violaçóes de direitos humanos e as inúmeras crises (alimentar, financeira, climática), todos os fenômenos que negam o sentido normativo passam a ser vistos como patologias, desvios em relaçăo à normatividade que retardam o alcance de uma idílica ordem cosmopolita que caracterizar-se-ia pela retomada do projeto kantiano de paz perpétua. Nos últimos anos, os recentes e recorrentes apelos da direita e esquerda brasileira em defesa da legalidade do "Estado Democrático de Direito" demonstram a força de um ideário que ignora a violência (nâo tăo) oculta da estrutura jurídica-política-econômica e naturaliza as relaçôes econômicas historicamente e socialmente construídas, fielmente acreditando que a correçăo da realidade em momentos de "crise" só pode ocorrer pelo aprimoramento normativo e por um "cálculo de correçấo": novas leis, novos princípios e uma nova moral.

Como seria possível romper com este tipo de abordagem hegemônica? Como compreender a especial dependência da política e do direito frente à economia global? Náo há nenhum interesse econômico na recém-aprovada Reforma Trabalhista? Na Reforma da Previdência? O crescente "processo de heterogeneizaçăo, fragmentaçâo e complexificaçâo da classe trabalhadora" (ANTUNES, 2015, p. 62) está descolado das alteraçóes econômicas que vêm caracterizando as últimas décadas? Tais processos poderiam ser resolvidos mediante o debate público e o apelo à cidadania? Por que estratégias discursivas, comunicativas, que trabalham com as noçóes de "reconhecimento" e "cooperativismo", nâo foram suficientes para frear o amplo processo de ataque aos direitos sociais que caracterizam os sucessivos planos de austeridade? 0 que a experiência grega tem a nos dizer sobre o alcance, eficácia e ideologia do nosso apego ao voto?

Todas essas questôes estáo intimamente relacionadas à desertificaçăo mundana acelerada pela guinada neoliberal e apontam, a título de aproximaçăo teórica, a necessidade de um tipo de abordagem que reincorpore o capitalismo como unidade analítica. Se a saída idealista perdeu o radar para simultânea situaçăo de cada vez 
mais riqueza concentrada e desemprego estrutural, com todas as suas consequências objetivas e subjetivas, a reaproximaçăo entre teoria crítica e crítica da economia política talvez seja capaz de reconstruir uma teoria crítica social (BONEFELD, 2014, p. 37), uma abordagem que uma vez mais volte a questionar: como a (atual) ordem social é possível? (LUHMANN, 1993, p. 195).

Comparado a outros autores de destaque no cenário liberal, Bobbio é aqui um bem-vindo ponto fora da curva. Diante das duas teses fundamentais do "Marx economista" que ainda demonstrariam, segundo Bobbio, sua atualidade e importância, a saber, (i) o primado do poder econômico sobre o poder político e (ii) a previsâo de que por meio do mercado tudo pode se tornar mercadoria (a chamada "mercadorizaçáo universal"), o desafio nessas primeiras décadas do século XXI é aceitar o convite feito em 1992 para que se releia Marx (BOBBIO, 2006, p. 299).

Nas próximas páginas, após apresentaçăo da importância e atualidade das críticas bobbianas ao neoliberalismo, bem como da defesa de um projeto democrático social, especialmente preocupado com uma específica relaçâo entre liberdade e igualdade, será sugerida uma proposta de (re)aproximaçăo entre Bobbio e marxistas, a partir de breve indicaçăo acerca do potencial de desenvolvimento crítico de alguns textos inéditos recentemente publicados (BOBBIO, 2014) que, curiosamente, vâo ao encontro da crítica ao giro antiprodutivista.

\section{A RELAÇÃO ENTRE LIBERDADE E IGUALDADE: IMPORTÂNCIA E ATUALIDADE DA ANÁLISE BOBBIANA}

É no contexto das discussōes que marcaram a proposta do "liberal-socialismo" que Bobbio apresentará algumas de suas reflexóes mais interessantes, em grande parte decorrentes da constataçâo de que nâo existe nenhum nexo histórico ou conceitual necessário entre democracia e liberalismo, nem entre socialismo e democracia (BOBBIO, 1983, p. 33). Durante os debates italianos da década de 1970 e 1980, em que muitos defendiam a necessidade de um salto qualitativo para a "autêntica sociedade socialista", as polêmicas quanto aos meios necessários para se atingir esse fim marcaram as intervençôes de Bobbio, cujas sucessivas aproximaçóes assinalavam sua defesa de um socialismo democrático. Daí a consideraçăo de Andrea Greppi, de que os estudos do autor italiano sobre a democracia "se desenvolveram em funçāo desse ideal liberal-socialista, como o único método possível, e por sua vez aceitável desde o ponto de vista ético, para a transformaçăo da sociedade" (GREPPI, 1998, p. 287).

Năo era outra a preocupaçăo bobbiana ao tematizar o "socialismo possível", que só poderia ser realizado na medida em que respeitasse as limitaçôes que o método democrático impóe, suas regras do jogo, ou "conjunto de regras de procedimento" (BOBBIO, 2000b, p. 22) que "estabelecem năo o que se deve decidir, mas sim apenas quem deve decidir e como" (BOBBIO, 2000c, p. 427). Trata-se aqui, naturalmente, de contrapor os fins possíveis e desejáveis à definiçâo mínima da democracia.

Diante da falta de concordância sobre o elemento que deveria servir de critério de distinçăo entre o que é ou năo é um regime socialista, Bobbio salientava que este, "em todas as suas diferentes e contrastantes encarnaçóes, significa, antes de tudo, uma coisa: mais igualdade" (BOBBIO, 1983, p. 39). Mas, assim como Bobbio procura 
esclarecer as diferenças de significado entre a liberdade segundo a doutrina liberal (enquanto năo impedimento) e a liberdade segundo a doutrina democrática (enquanto nâo constrangimento) (BOBBIO, 2015, p. 249), é fundamental especificar em que sentido "ao dizer 'mais igualdade' quero dizer também mais liberdade" (BOBBIO, 1999, p. 40).

Uma vez que o único nexo social e politicamente relevante entre liberdade e igualdade é aquele em que a liberdade é considerada como aquilo em que os membros de um determinado grupo social săo ou devem ser iguais (BOBBIO, 2009, p. 05), o que importa destacar é a perspectiva da igualdade na liberdade, isto é, igual liberdade como reciprocidade de poder:

"A maior causa da falta de liberdade depende da desigualdade de poder, isto é, depende do fato de haver alguns que têm mais poder econômico, político e social do que outros. Portanto, a igualdade do poder é uma das maiores condiçóes para $o$ crescimento da liberdade" (BOBBIO, 1999, p. 41).

Já presente no curso Teoria da justiça: Liçôes de filosofia do direito, de 1953, essa ideia era entăo articulada com o conceito de justiça enquanto "ordenamento da igual liberdade" (BOBBIO, 2012, p. 119). Em outras palavras, a relaçăo entre liberdade e igualdade se manifesta naquela fundamental articulaçăo entre "liberdades de" (liberdades civis) e "liberdades para" (direitos sociais, econômicos e culturais). Aqui deve-se ressaltar que a "liberdade para" atribui ao indivíduo nâo apenas a faculdade, mas também o poder para fazer. É este empoderamento que suporta e garante que as "liberdades de" nâo sejam mera forma abstrata de igualdade.

Como bem destacado por Bobbio, "se houvesse apenas as liberdades negativas, todos seriam igualmente livres, mas nem todos teriam igual poder" (BOBBIO, 2000c, p. 504). Este é o significado atual da liberdade após a passagem da liberdade hobbesiana como liberdade negativa (nâo-impedimento) para a liberdade rousseauniana como autonomia, e da transmutaçăo desta para uma concepçâo positiva da liberdade, em que aquilo que conta é o poder positivo, isto é, "capacidade jurídica e material de tornar concretas as abstratas possibilidades garantidas pelas constituiçóes liberais" (BOBBIO, 2000c, p. 489) algo que vai muito além da célebre distinçâo de Isaiah Berlin entre "liberdade negativa" e "liberdade positiva", que recusava a ideia de que a privaçăo material implicava reduçăo da liberdade (MIGUEL, 2016, p. 33).

A grande vantagem deste tipo de abordagem está em reconhecer a importância das condiçóes sociais para o exercício da liberdade. Considerar os indivíduos como pessoas sociais, isto é, inscritas na materialidade da sociedade, implica o reconhecimento de outros direitos, "tais como os direitos sociais, os quais devem colocar cada indivíduo em condiçôes de ter o poder para fazer aquilo que é livre para fazer" (BOBBIO, 2000c, p. 489). Esta concepçâo também demarca um tipo de compreensâo muito particular do indivíduo. A concepçăo individualista presente na repetida frase de que "a democracia moderna repousa em uma concepçâo individualista da sociedade", em Bobbio, năo prescinde da consideraçăo de que o homem é também um ser social. E o que isso significa?

Trata-se aqui da diferenciaçăo entre o individualismo da tradiçăo liberal-libertária e o individualismo da tradiçăo democrática: o primeiro, ao arrancar o indivíduo 
do corpo social, isola-o e condena-o a lutar pela própria sobrevivência, em que cada um deve cuidar de si mesmo em luta perpétua, ao passo que o segundo busca reconciliar o indivíduo com a sociedade, sendo esta o resultado de um livre acordo. Segundo Bobbio, "o primeiro faz do indivíduo um protagonista absoluto, fora de qualquer vínculo social. O segundo faz dele o protagonista de uma nova sociedade" (BOBBIO, 2000c, p. 383).

Năo por outra razăo, em entrevista a Nello Ajello no ano de 1995, Bobbio, ao abordar a democracia como forma de governo em que todos sáo igualmente livres, salientava que esta igualdade também requereria o reconhecimento dos direitos sociais essenciais (educaçāo, trabalho, saúde) que "tornam possível um melhor exercício dos direitos de liberdade. Os direitos sociais, o compromisso de satisfazê-los e defendê-los: eis o critério fundamental para distinguir a esquerda da direita" (BOBBIO, 1998, p. 119).

Em 1996, ao retomar o tema acerca da antítese entre liberalismo e socialismo, Bobbio volta a afirmar a compatibilidade entre os dois termos, por considerar "que o reconhecimento de alguns direitos sociais fundamentais [educaçăo, trabalho e saúde] seja o pressuposto ou a precondiçáo para um efetivo exercício dos direitos de liberdade" (BOBBIO, 2000c, p. 508). Daí a conceituaçâao "sintética" da democracia "que tem por fundamento o reconhecimento dos direitos de liberdade e como natural complemento o reconhecimento dos direitos sociais ou de justiça" (BOBBIO, 2000c, p. 502).

Mas é justamente no "projeto de democratizaçấo" que as dificuldades se mostram com toda a força e nitidez, principalmente para a esquerda. Se esta, por exemplo, teve no reconhecimento dos direitos sociais a maior materializaçâo de sua razâo igualitária (BOBBIO, 2001, p. 125), para além do conhecido desafio político frente aos direitos dos homens ("năo é tanto o problema de justificá-los, mas o de protegê-los" (BOBBIO, 2004, p. 23)), e do pessimismo manifestado ao se constatar a nâo realizaçâo destes ("o novo ethos mundial dos direitos dos homens resplandece apenas nas solenes declaraçôes internacionais e nos congressos mundiais que os celebram e comentam" (BOBBIO, 2000c, p. 677)), subsiste a constataçáo da ineficácia de participaçáo democrática na área dominada pelo poder econômico.

Como salienta Bobbio, é um fato que tanto nos estados capitalistas como nos socialistas, as grandes decisóes de política econômica săo tomadas autocraticamente, constataçăo a partir da qual lançava-se a inquietante pergunta, ainda em 1976: "quem pode excluir a hipótese de que exista um limite de tolerância do sistema, de tal forma que o sistema se despedace somente para náo se dobrar às exigências? (BOBBIO, 1983, p. 90). O atual despedaçamento neoliberal da democracia liberal manifestado no desmonte de qualquer resquício de programas sociais, nos violentos ataques aos direitos dos trabalhadores, no direcionamento explícito do direito para a "recuperaçâo da economia", nâo parecem ser bons indícios do tal "limite de tolerância"? No âmbito da "economia financeirizada" năo restam dúvidas de que no embate entre aqueles dois tipos ideais de indivíduos, o liberal e o democrático, este foi derrotado por aquele (BOVERO, 2015, p. 24).

Frente a isso, nâo seria possível suspeitar que as dificuldades de avanço na concepçăo da igualdade na liberdade traduzem um questionamento do núcleo teórico daquele "socialismo possível" caracterizado pelo método democrático? Quando Bobbio questiona se "é possível a sobrevivência de um Estado democrático numa sociedade 
náo democrática?" (BOBBIO, 2000b, p. 68), nâo deveríamos, entăo, perguntar "se a desejada democratizaçâo de outros âmbitos da sociedade é efetivamente possível"? (GREPPI, 1998, p. 295). Se até mesmo aquele parâmetro normativo (restrito) das regras do jogo năo encontra guarida nas "democracias" de hoje em dia, se aqueles dois elementos nucleares do liberal-socialismo, a igualdade e a liberdade, estăo em decadência nítida - a primeira, por se afogar "em quase toda a parte, numa enxurrada de cultura anti-igualitária", a segunda, por ser arrastada "pelo poder das oligarquias globais" e reduzida "a um simulacro pela colonizaçăo midiática das consciências" (BOVERO, 2015, pp. 35, 41) -, como compreender essas alteraçôes?

\section{DIÁLOGOS COM OS MARXISTAS E OS "NOVOS ESCRITOS SOBRE MARX”}

Se os debates que marcaram as décadas de 1950 e 1970, reunidos em Política e cultura, Nem com Max nem contra Marx e em Qual socialismo?, demonstraram a fecundidade que o diálogo entre liberais e marxistas pode ter, a recente publicaçáo de Escritos sobre Marx: Dialética, Estado, sociedade civil talvez possa contribuir para a atual necessidade de construçăo de um terreno crítico comum como forma de reaçáo à hegemonia neoliberal.

A partir dos textos até agora traduzidos para o português, pode-se dizer (de forma generalíssima) que Bobbio, na década de 1950, foi fundamental para a análise crítica de certo marxismo messiânico e de uma reduçáo das conquistas liberais às "garantias burguesas", defendendo, em polêmicas com comunistas italianos, que um regime democrático deve náo só remover a desigualdade de poder econômico, político e cultural, mas também garantir os limites do poder estatal. Daí sua discussăo com Togliatti, em que afirma ser muito fácil desembaraçar-se do liberalismo se este for identificado com uma teoria e prática da liberdade como poder, isto é, como poder da burguesia, mas muito difícil se o mesmo foi considerado "como a teoria e a prática dos limites do poder estatal, sobretudo numa época como a nossa na qual reaparecem tantos Estados onipotentes" (BOBBIO, 2015, p. 372).

Já na década de 1970, os debates acerca da inexistência de uma teoria marxista do estado socialista, do projeto democrático da esquerda frente à democracia representativa e quanto à compatibilidade entre o projeto de transformaçâo socialista e a permanência da democracia, levaram Bobbio a criticar o chamado "abuso do princípio de autoridade", destacando, por exemplo, que talvez fosse mais sábio utilizar a obra de Marx "para aquilo em que é ainda utilizável, para dela tirar instrumentos adaptados à análise da sociedade contemporânea" (BOBBIO, 1983, p. 40).

Hoje, esta mesma metodologia poderia servir como base para dar conta das duas teses gerais já mencionadas que, na década de 1990, ainda conservavam, segundo Bobbio, a força de Marx (BOBBIO, 2006, p. 305). Em um cotidiano marcado pela expressiva "vitória do mercado" e pelo retorno violento da direita neoconservadora, parece ser ainda mais urgente retomar as liçóes de Bobbio, que sabia muito bem que o mercado, ao mesmo tempo em que cria riqueza e libera imensas energias, também cria enormes e intoleráveis desigualdades e, por isso mesmo (de forma absolutamente coerente com o critério igualdade/desigualdade que norteia sua distinçăo entre direita e esquerda), essa vitória significa, também, năo o fim da esquerda (e muito 
menos o propagado "fim da história"), mas a contínua "recriaçăo das condiçôes para a sua perpetuaçăo" (BOBBIO, 1995, p. 68).

Esse movimento possibilita uma retomada do "liberalismo de esquerda" (Bobbio) frente ao "liberalismo de direita" (Hayek) (BOVERO, 2002, p. 94). Se Bobbio salientava năo saber como os potentados econômicos e financeiros movem o mundo, para entáo questionar, se "valerăo ainda as regras do Estado democrático e de direito, que até agora foi nosso modelo ideal?", se "sobreviverá a distinçâo entre o que é lícito e o que é ilícito?" (BOBBIO, 2016, p. 81), algumas das "linhas de convergência" com o marxismo - que o próprio Bobbio colocava em 1975 como factíveis de um novo momento de aproximaçăo - podem ser hoje retomadas e, assim, contribuir para a consolidaçáo de uma nova agenda de pesquisa que busque melhor compreender de que maneira o neoliberalismo se articula com a democracia.

No que consistiria, entăo, essa reaproximaçăo? É certo que, de modo geral, o leitor familiarizado com as discussōes anteriores entre "Bobbio e o marxismo" encontrará nesta última compilaçâo de artigos marxistas a retomada de algumas consideraçôes bastante conhecidas. No entanto, também descobrirá alguns textos ${ }^{2}$ que apresentam reflexōes até entāo inéditas que merecem atençâo. Em especial, sua análise histórica do marxismo teórico italiano pode ser particularmente útil para compreender que tipo de análise marxista Bobbio considerava interessante naquele período e como isso se mantém atual nos dias de hoje.

Uma vez que nosso autor pertence a uma geraçâo que estudou Marx a partir da crítica feita por Croce às teses de Labriola, é importante considerar o tipo de leitura que caracterizou a chamada primeira fase do marxismo teórico na Itália. Trata-se, aqui, de uma leitura filosófica (também presente em Gentile) de Marx que objetivava liquidá-lo enquanto filosofia. Existia entăo uma estratégia muito bem articulada: Labriola procurou desconstruir a associaçăo entâo dominante entre marxismo e positivismo, reunindo esforços para libertar os escritos marxianos de uma interpretaçáo positivista. Essa tentativa, no entanto, suscitou um grande alarme entre os expoentes da filosofia burguesa. E năo seria para menos. Como bem destacado por Bobbio, o marxismo interpretado pelas lentes do positivismo era simplesmente inócuo, já que, positivado, "poderia ser considerado um aspecto secundário da filosofia burguesa e, assim, poderia enquanto tal ser facilmente digerido e neutralizado" (BOBBIO, 2014, pp. 61-62). Da mesma forma, se identificado com o positivismo, a superaçấo deste pelo idealismo também levaria irremediavelmente à superaçâo do próprio marxismo. É neste preciso sentido que a primeira fase do marxismo italiano é conceituada enquanto uma negaçăo filosófica.

Mas após a guerra, a segunda fase do marxismo teórico na Itália, influenciada pela robustez do movimento operário, pela publicaçâo de escritos entăo inéditos de Marx e pela ruptura com a espiritualidade romântica, procurou afirmar, também no plano filosófico, o aspecto decisivo do marxismo (com autores como Del Noce, Balbo e Della Volpe) (BOBBIO, 2014, p. 31).

Em especial, Il marxismo teorico in Italia (1951), Il marxismo teórico in Italia (1958), Italo-marxismo (1967), Marxismo e scienze sociali (1975), La Storia del marxismo Einaudi (1978) e Marx vivo? (1983). 
Ainda que Bobbio saliente que o "ítalo-marxismo" é caracterizado pela interpretaçăo náo materialista de Marx, que culmina em uma leitura hegeliana do mesmo, ou seja, seu enquadramento como uma fase do pensamento filosófico europeu, razâo pela qual "a característica dos italianos - impregnados de hegelianismo - é a operaçăo de reconduzir Marx a Hegel para enobrecê-lo" (BOBBIO, 2014, p. 39), o pensador de Turim náo deixava de salientar que o referido aspecto decisivo de Marx estaria na descoberta da tese do materialismo histórico e da filosofia da práxis (BOBBIO, 2014, p. 64). É essa compreensâo contextualizada do tipo de marxismo (filosófico) que predominou na Itália até a década de 1960 que pode ser considerada a primeira contribuiçâo de alguns dos textos inéditos de Bobbio sobre Marx recentemente publicados.

A segunda contribuiçâo parece estar intimamente associada à anterior, uma vez que problematiza em que medida outro tipo de marxismo poderia ser desenvolvido a partir das inúmeras abordagens marxistas que surgem a partir da década de 1960. Em um texto também denominado "Marxismo e ciências sociais" ${ }^{3}$, Bobbio demonstra estar absolutamente a par das controvérsias do período. "O que se entende hoje por marxismo? Tantos marxismos" (...). O marxismo, afirmava, năo é mais um universo, mas um pluriverso" (BOBBIO, 2014, p. 103).

Diante disso, inúmeras perguntas apareciam: qual seria o denominador comum para ser considerado marxista? Uma concepçăo do mundo? Um método específico? Possuir uma filosofia da história? Ou uma crítica política? É necessário um certo modo de fazer filosofia ou de fazer política? O materialismo? Qual materialismo? E assim por diante... Bobbio reconhece que naquela época ninguém refutaria totalmente Marx, assim como provavelmente ninguém o aceitaria integralmente. O problema estava justamente neste espaço intermediário, "que deixa aberta a possibilidade das posiçóes mais diferenciadas: o náo-marxista, o filo-marxista, o quase-marxista, o neomarxista, o marxista tout court, etc" (BOBBIO, 2014, p. 105).

Ainda assim, diante da dupla constataçăo de que "nenhum dos grandes personagens da cultura italiana foi marxista (Croce Gentile, Salvemini, Einaudi)", e de que existem obras de Marx que constituem um momento importante para o estudo da sociedade humana, "năo se pode negar que essas obras tiveram e têm crescentemente uma enorme influência sobre as ciências que se ocupam do homem em geral e do homem social em espécie" (BOBBIO, 2014, p. 105). Conclusăo: "necessidade do encontro" (BOBBIO, 2014, p. 107). Após os debates das décadas passadas com autores marxistas, em que sentido isso poderia acontecer?

Bobbio menciona, entăo, as já mencionadas "linhas de convergência": em primeiro lugar, a ideia da autonomia relativa do político. O que isso significa? Citando as reflexôes de Poulantzas, a esfera política náo seria um puro e simples reflexo daquilo que ocorre na esfera das relaçóes de produçăo e de classe, tendo por isso mesmo uma funçấo específica, qual seja constituir um fator de coesăo social dos vários níveis da formaçấo social, isto é, "como forma de regulaçâo do equilíbrio global de uma

Em 1974 é publicada uma conferência de Bobbio que ocorreu em 1972, em Catania, no seminário Ciências sociais e marxismo, cujo título também é "Marxismo e ciências sociais" (este texto foi inserido na coletânea Nem com Marx nem contra Marx). Apesar da mesma nominaçăo, os textos săo diferentes. 
formaçăo social, enquanto sistema" (BOBBIO, 2014, p. 110). Daí a própria afirmaçăo de Bobbio, de que a teoria da autonomia do político poderia ser "um bom ponto de encontro entre aqueles que partem de Marx e aqueles que partem de outros pontos de vista. Um ponto de encontro e de fecunda discussăo" (BOBBIO, 2014, p. 110).

Outro tema que poderia contribuir para essa (re)aproximaçâo com a literatura marxista está no processo de burocratizaçấo do Estado. Aqui Bobbio destaca a dificuldade de se compreender tal fenômeno com aquele outro processo paralelo da democratizaçâo das instituiçôes públicas, destacando que, se um dos temas da ciência política năo marxista é a transformaçăo do estado em um grande aparato, e se "o nosso destino depende de qual dos dois processos superará o outro", entâo "marxistas e năo marxistas têm que se beneficiar das pesquisas de uns e dos outros" (BOBBIO, 2014, p. 111).

Por fim, o problema da democracia é apresentado por Bobbio como sendo uma terceira linha de convergência com os marxistas: Após salientar que os marxistas corrigiram - e muito - seu alvo, e que uma discussăo como aquela que aconteceu nos anos 1950 seria naquele momento (o artigo é de 1975) improvável, Bobbio reconhece que o "democratismo fácil" de autores liberais seria entăo impossível. Se naquele período ninguém poderia refutar algumas propostas marxistas de alargamento das bases democráticas do poder, características do chamado programa da democracia radical, ninguém também poderia ignorar a experiência secular da democracia chamada primeiramente de "burguesa", sem a qual nâo existiria nem democracia burguesa nem democracia năo burguesa. $\mathrm{O}$ arremate? "Aqui está um grande terreno de encontro, desde que seja explorado sem preconceitos, sem falsidade, sem recorrer ao ipse dixit" (BOBBIO, 2014, p. 111).

Mas a indicaçăo temática que permitiria a continuidade de um debate com os marxistas, apesar de importante, nâo constitui o núcleo duro de sua segunda contribuiçâo, muito mais próxima do modo como os próprios temas vinham à tona, e que diz respeito à potencialidade da crítica da economia política (ao invés da ênfase na discussăo filosófica). Em um artigo que buscava contribuir para a chamada "crise do marxismo", Bobbio já salientava um aspecto crucial, qual seja a prevalência de estudos sobre o "Marx filosófico" em detrimento do "Marx economista", afirmando que "diante da massa infinita e agora crescente de estudos sobre O Capital e sobre todas as obras econômicas de Marx, há uma certa desproporçăo entre os estudos dedicados às suas obras filosóficas e políticas, e aqueles dedicados à crítica da economia política" (BOBBIO, 2014, p. 116).

Coerentemente, ao ler um ensaio de Robert Heilbroner que exaltava Marx como o maior filósofo depois de Platăo e como inventor da ciência crítica da sociedade, dizia: "Estou de acordo. Mas o que se entende por crítica? Certamente existem vários significados, mas quais săo? Me pergunto: năo teria sido mais interessante um ensaio 'Marx crítico', 'Marx e a crítica', mais que ‘Marx filósofo'?". (BOBBIO, 2014, p. 117). Nâo satisfeito, além de indicar a importância de se incluir em uma "história do marxismo" os estudos sobre ciência e ideologia, muitas vezes esquecidos, Bobbio considerava fundamental escrever algo como "Marx sociólogo", ou "Marx e a teoria da sociedade", salientando que năo existiria sociólogo naquele período que náo travasse contato com ele (Pareto e Marx, Durkheim e Marx, Weber e Marx, Parsons e Marx): “a obra de Marx é a mais grandiosa tentativa feita até agora de elaborar nâo somente 
uma teoria global da sociedade, mas de encontrar as linhas de desenvolvimento da sociedade humana como um todo. Tudo isso se chama hoje sociologia, goste ou náo goste" (BOBBIO, 2014, p. 118).

Do exposto até aqui năo resta dúvidas de que Marx estava "vivo". Como disse Robert Kurz em sua compilaçăo dos textos marxianos mais importantes para o século XXI: "Tot gesagte leben länger" [Aqueles de quem se diz estarem mortos vivem mais] (KURZ, 2001, p. 15). Ao que Bobbio já considerava: "Marx está vivo? Vivo sim, pelo fato de que ninguém pode hoje prescindir de Marx", ainda que "vivo năo queira dizer válido" (BOBBIO, 2014, p. 120). As ponderaçōes do pensador turinês sâo uma vez mais extremamente sugestivas. Mesmo diante dos recorrentes abusos de autoridade e revisionismos que tanto marcaram a marcha histórica do marxismo em busca do "verdadeiro Marx", Bobbio serenamente coloca a vitalidade e validade de Marx naqueles dias (o artigo é, provavelmente, de 1983) da seguinte forma:

"Trata-se de saber se podemos prescindir de Marx para compreender o mundo contemporâneo, ou ao menos uma parte. Eu creio que nâo [...] Nấo se pode negar que enquanto existir a sociedade capitalista a crítica marxiana nâo perderá nada de sua extraordinária força subversiva" (BOBBIO, 2014, p. 121).

Qual o significado dessas consideraçôes, que incluem a "impressâo de que a palavra final cabe aos economistas", para uma proposta de retomada de encontros entre liberais e marxistas no âmbito da atual hegemonia neoliberal? Qual a importância das duas contribuiçóes (em primeiro lugar, a caracterizaçăo das leituras marxistas na Itália até a década de 1960 como predominantemente filosóficas; em segundo lugar, a percepçăo de que uma abordagem pautada na crítica da economia política poderia levar o marxismo a caminhos possivelmente mais frutíferos) ${ }^{4}$ nos dias de hoje?

\section{PARA UMA RETOMADA DO CAPITALISMO COMO CATEGORIA ANALÍTICA}

O liberalismo de Bobbio, como se sabe, é político, e năo econômico. Ou seja, Bobbio jamais foi um liberista. Ainda que seu compromisso liberal estivesse pautado na defesa intransigente dos direitos e garantias políticos, nem por isso suas reflexóes deixaram de atentar para a especial relevância das questóes sociais. Como salienta Perry Anderson, Bobbio "é como um Mills que havia conhecido Marx" (ANDERSON, 1989, p. 24). Mas năo só.

\footnotetext{
"Mais frutíferos", tal como um observador liberal os veria. Como a análise fragmentada é o próprio ponto cego do liberalismo (cuja distinçăo "política" e "economia" é característica), as próprias análises liberais do marxismo separam a totalidade marxiana em "setores", níveis", "esferas", o que por si só já é uma limitaçáo importante. Daí a necessidade de se evitar o rasteiro argumento de que no marxismo haveria uma espécie de determinismo econômico. Basta, aqui, retomar Lukács: "Nâo é o predomínio de motivos econômicos na explicaçáo da história que distingue de maneira decisiva o marxismo da ciência burguesa, mas o ponto de vista da totalidade"(LUKÁCS, 2012, p. 105).
} 
Anderson destaca que seria possível compará-lo a Habermas, cuja trajetória seria mais ou menos o inverso do itinerário de Bobbio, ${ }^{5}$ tendo como resultado uma síntese muito mais vasta e sistemática (tal como em Teoria da açâo comunicativa). Mas a principal separaçăo frente ao autor alemăo estaria na influência do já mencionado realismo político. De certa forma, e isto é fundamental para os propósitos do presente artigo, é a apropriaçăo da tradiçâo realista italiana (Maquiavel, Mosca, por exemplo) e seu redirecionamento para as questôes do Estado que mantêm Bobbio distante do referido giro antiprodutivista da teoria social.

Apesar do inegável mérito de nâo cair em especulaçôes comunicativas, isso năo impede que sérios questionamentos sejam feitos à abordagem bobbiana. Se nela, por um lado, náo encontramos aquele tipo de reflexăo liberal que desqualifica questionamentos acerca da relaçâo entre distribuiçấo de riquezas e desigualdade, capitalismo e igualdade (PHILLIPS, 1999, p. 10-19), por outro, "o capitalismo como tal é para Bobbio pouco mais que um vago horizonte referencial: rechaçado, sim, mas analisado, năo" (ANDERSON, 1989, p. 31).

As críticas de Bobbio à "democracia representativa", segundo Anderson, representariam "os pontos verdadeiramente nevrálgicos do pensamento bobbiano, nos quais se podem ver as tensōes intelectuais que o penetram e subjazem" (ANDERSON, 1989 , p. 28). Isso manifestar-se-ia na seguinte incompatibilidade: na mesma década de 1980, as chamadas "promessas năo-cumpridas da democracia" (sobrevivência do poder invisível, permanência das oligarquias, supressăo dos corpos intermediários, revanche da representaçăo dos interesses, participaçăo interrompida, ausência de uma educaçăo para a cidadania) (BOBBIO, 2000b, pp. 34-35) significariam a percepçăo de falhas internas à democracia, fruto de "processos implacáveis" (ANDERSON, 1989, p. 29). No entanto, no mesmo período, Bobbio também criticaria a democracia representativa por aquelas promessas que jamais formulou, referentes à democratizaçăo da própria sociedade, e nâo do Estado (BOBBIO, 2000b, p. 68). Estas, no entanto, seriam falhas năo necessárias, potencialmente superáveis através de uma extensăo dos próprios princípios democráticos.

Conforme a avaliaçâo de Anderson, năo seria possível sustentar as duas críticas simultaneamente: "ou entăo a democracia representativa está destinada fatalmente a uma contraçâo de sua substância, ou está disposta virtualmente à extensâo dessa substância. Ambos os termos náo podem ser verdadeiros ao mesmo tempo" (ANDERSON, 1989, p. 29). Ora, é bem verdade que, para Bobbio, as situaçôes a partir das quais se originavam as promessas năo cumpridas nâo permitiam a avaliaçăo de que existiria uma "degeneraçăo" da democracia, "mas sim de adaptaçăo natural dos princípios abstratos à realidade ou de inevitável contaminaçấo da teoria quando forçada a submeter-se às exigências da prática" (BOBBIO, 2000b, p. 20).

Náo se pode esquecer, no entanto, que tais exigências estavam associadas a três obstáculos decorrentes do entăo Estado de Bem-Estar: (i) aumento dos problemas políticos que requerem competências técnicas (tecnocracia e democracia sâo antitéticas); (ii) contínuo crescimento do aparato burocrático (a burocracia pressupóe

Habermas partiu do marxismo para, depois, descobrir a herança ideal e política do liberalismo pragmático, náo através de Mill e Tocqueville, já criticados pelo autor frankfurtiano, mas de Dewey e da tradiçăo pragmática estadunidense. 
um poder ordenado hierarquicamente, ao passo que democracia pressupóe um poder democrático) e (iii) ingovernabilidade da democracia decorrente da quantidade e rapidez com que as demandas da populaçáo chegam ao sistema político (a democracia tem a demanda fácil e a reposta difícil) (BOBBIO, 2000b, pp. 46-49).

Ocorre que as correntes neoliberais, ${ }^{6}$ onde quer que tenham ganhado terreno, procuraram legitimar suas açóes mediante o ataque aos "problemas" do Welfare State, como se tais medidas permitissem năo só enfrentar a estagflaçăo econômica da década de 1970, como também inverter a queda na taxa de lucro e, supostamente, retomar o crescimento econômico. E quais foram essas medidas? No plano nacional isso foi alcançado mediante (i) o combate aos sindicatos e aos movimentos operários, a (ii) restriçấo ao intervencionismo estatal na economia e a (iii) abrupta diminuiçấo da regulamentaçáo social (em outras palavras: rever a legislaçáo tributária em benefício das elites econômicas como forma de favorecer o investimento para "todos", no chamado efeito trickle-down, ${ }^{7}$ e a necessidade de cortar investimentos em serviços sociais), o que garantiu uma expressiva queda nos custos do trabalho e uma super-exploraçăo da classe trabalhadora. Já no plano internacional, a chamada Crise do Petróleo (com a conivência do EUA) garantiu um estratégico aumento dos custos de energia que náo só deteriorou as bases da produçấo alemá e japonesa (que passaram a concorrer com os EUA pelo domínio do mercado mundial), como também favoreceu o deslocamento dos petrodólares para a entáo fervilhante Wall Street. 0 que permitiu isso?

A estagflaçăo e as rígidas normas que caracterizavam o Acordo de Bretton Woods - com um sistema de taxas de câmbio fixas - ameaçavam a posiçăo do dólar como moeda global na década de 1970, já que os EUA acumulavam tanto um déficit fiscal quanto um déficit comercial, fruto da articulaçáo dos custos da "Grande Sociedade" de Kennedy e da Guerra do Vietnă. Neste cenário, a política de juros do FED foi essencial para manter a atratividade do dólar e seu status internacional. Evidentemente, este năo seria um livre acordo entre Estados soberanos, alcançável mediante o livre debate de ideias e o reconhecimento recíproco dos interesses das partes envolvidas. Bem distante do receituário que prevê um fórum democrático como instância legitimadora para decisóes vinculantes desse tipo, em 1979, logo após a nomeaçăo de Paul Volcker como presidente da referida instituiçấo, as taxas de juros médias subiram inacreditáveis 11\%. Em junho de 1981, os juros subiram para 20\%, e depois novamente para 21,5\% (VAROUFAKIS, 2016, p. 133). Resultado: nâo só os produtores de petróleo năo americanos substituíram seus ganhos por títulos do governo norte-americano. Amplos setores da indústria japonesa e alemă, que forçadamente precisaram reagir ao choque do petróleo através da transferência de seus investimentos em atividades intensivas para empreendimentos de alta tecnologia, passaram a direcionar seus lucros para Wall Street. Como salienta Varoufakis,

\footnotetext{
6 Como salientam Dardot e Laval, “o neoliberalismo vai desenvolver-se segundo várias linhas de força, submetendo-se a tensōes das quais devemos reconhecer a importância. O colóquio de 1938 [Colóquio Walter Lipmann] revelou discordâncias que, desde o princípio, dividiram os intelectuais que reivindicavam para si o neoliberalismo" (DARDOT; LAVAL, 2016, p. 72).

7 "O efeito trickle-down foi concebido para legitimar reduçōes nas taxas de impostos para os ricos, sugerindo que seu dinheiro extra escorreria para os pobres. Todas as evidências empíricas desmontam essa hipótese. Simplificando, isso nunca aconteceu". (VAROUFAKIS, 2016, p. 170).
} 
"E o que Wall Street fazia? Transformava instantaneamente esses influxos de capital em investimentos diretos, açóes, novos instrumentos financeiros, novas e velhas formas de empréstimo e, por último, mas não menos importante, num "bom rendimento" para eles próprios, os banqueiros. Sob este prisma, tudo (o aumento da financeirizaçáo, o triunfo da ambiçâo, o recuo dos reguladores e o domínio do modelo de crescimento anglo-celta) parece fazer mais sentido" (VAROUFAKIS, 2016, p. 52).

Levando essas breves reflexões em conta fica muito mais fácil compreender a "simultaneidade bastante perturbadora" indicada no início do artigo. Não só saltam aos olhos as razões pelas quais uma riqueza financeira cada vez maior está intimamente relacionada à super-exploração da "classe-que-vive-do-trabalho" (ANTUNES, 2009, p. 101), como soam particularmente rasas e enganadoras as saídas normativas apresentadas pelo mainstream teórico que pretende orientar o mundo pela ênfase na dimensão comunicativa das pessoas, pelo apelo à norma e o desejo de "cidadania". Ainda que embrionária, esta breve pitada de crítica da economia política demonstra não só o acerto da segunda contribuição de Bobbio quanto à produtividade de análises que substituíssem a ênfase no "Marx filósofo" pelo "Marx economista", como também sugere seu vigor para compreendermos o motivo pelo qual Bobbio é, hoje, muito mais atual do que Habermas e seus diagnósticos apressados.

\section{CONSIDERAÇÕES FINAIS}

No espectro político atual nâo há qualquer sinal de ver questôes como essas serem pautadas com a devida atençâo e profundidade. Năo há "saída democrática" sem questionamento do poder do mercado financeiro nos dias de hoje e do modo de produçâo de ordem na sociedade capitalista, ainda que parte considerável da esquerda politicamente organizada sequer problematize nossa situaçâo de dependência e violência crescentes. Após a experiência da Grécia, a suspeita de Bobbio - "frequentemente, tenho a impressáo de que nesse universo continuamos a discutir sobre ideias, enquanto o que conta agora săo os grandes interesses econômicos e financeiros, que passam por cima da política e náo estâo muito preocupados com a cultura" (BOBBIO, 2016, p. 81) - revelou-se amargamente fundada. Um intento real de enfrentar esta situaçăo, no entanto, precisa urgentemente acertar as contas com a estratégia idealista de resoluçáo dos problemas.

Naturalmente, isso náo significa năo refletir sobre as melhores estratégias de enfrentamento do neoliberalismo (PRADELLA; MAROIS, 2015), nem panfletar discursos de ruptura imediata contra a ordem vigente. O mundo material, repleto de seres humanos desempregados, com fome e năo poucas vezes sem qualquer assistência social, vivenciando e reproduzindo a violência constante do nosso cotidiano, é um contrapeso fundamental para barrar saídas desse tipo. Mas isso também nâo autoriza que continuemos reféns daquele tipo de reformismo rasteiro que abdica dos enfrentamentos posteriores em nome de uma suposta "coalizâo de interesses", "políticas públicas inclusivas" e projetos "nacionais" de desenvolvimento que caracterizam e continuam a caracterizar o "projeto neoliberal para a sociedade brasileira" (PAULANI, 2008, p.105). 
Frente a isso, tome-se como exemplo a recente demanda por "direitos sociais globais", um tema que, certamente, seria tăo caro a Bobbio, e que sintetiza uma possível agenda contra-hegemônica de atuaçâo, sensível aos problemas estruturais que perpassam o globo capitalista (FISCHER-LESCANO; MÖLLER, 2017, p. 03). Trata-se, assim, de uma reivindicaçăo que se situa numa perspectiva crítica à chamada "globalizaçăo" e que procura vincular os "direitos sociais globais" aos direitos humanos sociais existentes a um projeto de solidariedade.

O tempo dirá se esse tipo de problematizaçăo - que procura disputar juridicamente as riquezas sociais ${ }^{8}$ - conseguirá ser mais do que um mero manifesto político. Garantir náo só o acesso, mas também efetivar os direitos à saúde, alimentaçâo, educaçăo e moradia (entre outros) é sem dúvida o primeiro passo para que a classe-quevive-do-trabalho sobreviva à barbárie neoliberal, mas jamais se pode esquecer que a sociedade capitalista "nâo se imuniza contra conflitos e contradiçôes, mas com a ajuda de conflitos e contradiçôes", e que "o campo jurídico de disputa hegemônica nâo altera os quadrantes da hegemonia do capital exercida no campo social" (BARREIRA, 2016, p. 336). Em síntese: o adversário sequer será adequadamente tematizado sem um efetivo combate ao idealismo jurídico. Diante da cegueira deliberada de grande parcela dos setores "críticos", a retomada da crítica da economia política apresentase como a única capaz de rasgar o véu ideológico que dia após dia rebaixa a humanidade aos desejos e caprichos da reproduçáo social capitalista.

8 Buckel é outra autora atual que defende o "potencial emancipatório do direito" (BUCKEL, 20070, p. 312). 


\section{REFERENCIAS BIBLIOGRÁFICAS}

ANDERSON, Perry. "Norberto Bobbio e a democracia moderna". Revista Novos Rumos. Ano 4, n. 15, 1989.

ANTUNES, Ricardo. Adeus ao trabalho? Ensaio sobre as metamorfoses e a centralidade do mundo do trabalho. 16. Ed. Săo Paulo: Cortez, 2015.

BARREIRA, C. M. "Autonomia jurídica: o problema da reificaçâo revisitado". In CUNHA, J. R. (Org.). Epistemologias Críticas do Direito. Rio de Janeiro: Lumen Juris, 2016.

BOBBIO, Noberto. Eguaglianza e libertà. Torino: Einaudi, 2009.

. “Tiene fututo el socialismo?", Temas para el debate. n. 2 (1995).

A era dos direitos. Rio de Janeiro: Elsevier, 2004.

. As ideologias e o poder em crise. Brasília: Editora Universidade de Brasília, 1999.

. Contra os novos despotismos: escritos sobre o berlusconismo. Săo Paulo: Editora Unesp; Instituto Norberto Bobbio, 2016.

. Diário de um século: autobiografia. Rio de Janeiro: Campus, 1998.

. Direita e esquerda: razōes e significados de uma distinçâo política. Săo Paulo: Editora UNESP, 2001.

. Liberalismo e democracia. Sáo Paulo: Brasiliense, 2000 (2000a)

. Nem com Marx, nem contra Marx. Sâo Paulo: Editora UNESP, 2006.

. O futuro da democracia. Sáo Paulo: Paz e Terra, 2000 (2000b)

. 0 tempo da memória: De senectute e outros escritos autobiográficos. Rio de Janeiro: Campus, 1997.

. Política e Cultura. Săo Paulo: Editora UNESP, 2015.

. Qual socialismo? Debate sobre uma alternativa. Rio de Janeiro: Paz e Terra, 1983.

. Scritti su Marx. Dialettica, stato, società civile. Roma: Donzelli Editore, 2014.

. Teoria della giustizia: lezionidi filosofia del diritto 1953. Torino: Nino Aragno Editore, 2012.

. Teoria geral da política: a filosofia política e as liçóes dos clássicos. Rio de Janeiro: Elsevier, 2000 (2000c)

BONEFELD, Werner. Critical Theory and the Critique of Political Economy. New York/ London: Bloomsbury, 2014.

BOVERO, Michelangelo. Contra o governo dos piores: uma gramática da democracia. Rio de Janeiro: Campus, 2002.

Para uma teoria neobobbiana da democracia. Sâo Paulo: FGV Direito SP, 2015. 
BUCKEL, Sonja. Subjektivierung und Kohäsion: Zur Rekonstruktion einer materialistischen Theorie des Rechts. Weilerswist: Velbrück Wissenschaft, 2007.

DARDOT, Pierre; LAVAL, Christian. A nova razăo do mundo: ensaio sobre a sociedade neoliberal. Sáo Paulo: Boitempo, 2016.

ELBE, Ingo. Marx im Westen: die neue Marx-Lektüre in der Bundesrepublik seit 1965. Berlin: Akademie Verlag, 2010.

FISCHER-LESCANO, Andreas; MÖLLER, Kolja. Luta pelos direitos sociais globais: o delicado seria o mais grosseiro. Rio de Janeiro: Lumen Juris, 2017.

GONÇALVES, G.L/COSTA, S (2016): "The Global Constitutionalization of Human Rights: Overcoming Contemporary Injustices or Juridifying Old Asymmetries?" Current Sociology 64(2).

GONÇALVES, Guilherme Leite: "Acumulaçăo primitiva, Direitos Humanos e Movimentos Sociais: Esboço de Uma Provocaçăo ao Giro Antiprodutivista". In CUNHA, J. R. (Org.). Epistemologias Críticas do Direito. Rio de Janeiro: Lumen Juris, 2016.

(2017): Acumulaçăo primitiva, expropriaçăo e violência jurídica: expandindo as fronteiras da sociologia crítica do direito. Revista Direito \& Práxis: Rio de Janeiro, v. 8, n. 2.

GONÇALVES, Guilherme Leite. Marx está de volta! Um chamado pela virada materialista no campo do direito. Revista Direito \& Práxis: Rio de Janeiro, v. 5, n. 9.

GRAHAM, Stephen. Cidades sitiadas: o novo urbanismo militar. Săo Paulo: Boitempo, 2016.

GREPPI, Andrea. Teoría e ideologia en el pensamento político de Norberto Bobbio. Barcelona: Marcial Pons, 1998.

GUMBRECHT, H. U.; PFEIFFER, K. L. Materialities of Communication. California: Stanford University Press 1994.

HABERMAS, Jürgen. Theorie des kommunikativen Handelns: Zur Kritik der funktionalistischen Vernunft. Band 2. Frankfurt am Main, 1987.

KURZ, Robert. Marx lesen! Die wichtigsten Texte von Karl Marx für das 21. Jahrhundert. Frankfurt am Main: EIchborn, 2001.

LAFER, Celso. Norberto Bobbio: trajetória e obra. Sāo Paulo: Perspectiva, 2013.

LUHMANN, Niklas. Gesellschaftsstruktur und Semantik. Frankfurt am Main: Suhrkamp Verlag, 1993.

LUKÁCS, György. História e consciência de classe: estudos sobre a dialética marxista. 2. ed. Săo Paulo: Martins Fontes, 2012.

MARX, Karl. 0 capital. Livro I. Săo Paulo: Boitempo, 2013.

MIGUEL, Luis Felipe (Org.). Desigualdades e Democracia: o debate da teoria política. Săo Paulo: Ed. UNESP, 2016.

PAULANI, Leda. Brasil delivery: servidăo financeira e estado de emergência econômico. Săo Paulo: Boitempo, 2008. 
PHILLIPS, Anne. Which Equalities Matter? Cambridge: Polity, 1999.

PIKETTY, Thomas. O Capital no século XXI. Rio de Janeiro: Intrínseca, 2014.

PRADELLA, Lucia; MAROIS (Ed.), Thomas. Polarising Development: alternatives to neoliberalism and the crisis. London: Pluto Press, 2015.

RICOBOM, Gisele. Intervençăo humanitária: a guerra em nome dos direitos humanos. Belo Horizonte: Fórum, 2010. 